\title{
NOTES
}

\section{SUPREME COURT EQUITY DISCRETION: THE DECREES IN THE SEGREGATION CASES*}

IN its decisions repudiating the doctrine of "separate but equal" in the field of public education, ${ }^{1}$ the Supreme Court called for further argument regarding an appropriate form of relief. ${ }^{2}$ Questions propounded by the Court center about three interlocking problems: (1) May the Court under its equity powers formulate a decree providing for gradual desegregation of the schools? (2) If so, what factors should determine the degree of gradualness? (3) What procedures should be followed in fixing the details of the decree ? ${ }^{3}$

\footnotetext{
*Brown v. Board of Education, 347 U.S. 483 (1954) ; Bolling v. Sharpe, 347 U.S. 497 (1954).

The decision in Brozem is a consolidated opinion incorporating four segregation cases from school districts in Kansas, South Carolina, Delaware, and Virginia. Bolling, dealing with segregation in the District of Columbia, was decided separately because of the different legal questions presented. See note 1 infra. Plaintiffs are Negro children of elementary
} and high school age residing in the five counties in which the suits were brought.

1. This doctrine interprets the Equal Protection Clause of the Fourteenth Amendment as allowing states to enforce separate use of public facilities by the Negro and white races so long as equal accommodations are afforded. It was adopted by the Supreme Court in Plessy v. Ferguson, 163 U.S. 537 (1896), upholding a state statute recuiring segregation in public transportation. For discussion of application of the Plessy rule to public education, see Note, 61 YaLE L.J. 730 (1952).

In Brown, the Court held segregated educational facilities to be inherently unequal, and hence violative of the Fourteenth Amendment's Equal Protection Clause, because of the inferiority feelings they engendered in Negro pupils. Brown v. Board of Education, 347 U.S. 483, 494 (1954). Since the Fourteenth Amendment does not apply to action by federal authorities, the Bolling case, concerning segregation in the District of Columbia, was decided under the Due Process Clause of the Fifth Amendment. The Court, however, found that the concepts of equal protection and due process were "not mutually exclusive," and held that segregation in the District of Columbia constituted an arbitrary deprivation of liberty in violation of due process. Bolling v. Sharpe, 347 U.S. 497, 499-500 (1954).

For analysis of the decisions in Brozen and Bolling, see Borinski, A Legal and Sociological Analysis of the Segregation Decision of May 17, 1954, 15 PITTs. L. REv. 622 (1954).

2. The original argument before the Supreme Court was held December 9-11, 1952. Although two of the five questions proposed by the Court in June, 1953, for reargument the following fall, related to the issue of implementing a decision abolishing educational segregation, the briefs and arguments naturally focused on the other three questions dealing with the constitutionality of segregation in public education. The Court therefore decided only the constitutional issue, asking for further reargument on the question of relicf. Brown v. Board of Education, 347 U.S. 483, 495-6 (1954). The cases are presently scheduled for final argument on December 9, 1954. N.Y. Times, Sept. 23, 1954, p. 1, cols. 4-5.

3. The questions read as follows:

"4. Assuming it is decided that segregation in public schools violates the Fourteenth Amendment 


\section{Legality of a Gradual Decree}

There is little precedent to guide the Court in determining whether its equity discretion admits of a gradual decree in these cases.* The Court has already decided that an equitably enforceable constitutional right exists; the only question is when enforcement is to come. ${ }^{b}$ Past judicial pronouncements as-

“(a) would a decree necessarily follow providing that, within the limits set by normal geographic school districting, Negro children should forthwith be admitted to schools of their choice, or

"(b) may this Court, in the exercise of its equity powers, permit an effective gradual adjustment to be brought about from existing segregated systems to a system not based on color distinction?

" 5 . On the assumption on which questions $4(a)$ and (b) are based, and assuming further that this Court will exercise its equity powers to the end deseribed in question 4 (b),

"(a) should this Court formulate detailed decrees in these cases;

"(b) if so, what specific issues should the decrees reach;

"(c) should this Court appoint a special master to hear evidence with a viev to recommending specific terms for such decrees;

"(d) should this Court remand to the courts of first instance with directions to frame decrees in these cases, and if so what general directions should the decrees of this Court include and what procedures should the courts of first instance follow in arriving at the specific terms of more detailed decrees?" Brown v. Board of Education, 347 U.S. 483, 495-6 (1954).

4. For cases from which analogies may be drawn, see notes 15-25 infra, and accompanying text.

5. Brozm and Bolling determined that plaintiffs have a constitutional right to nonsegregated education. Brown v. Board of Education, 347 U.S. 483, 495-6 (1954); Bolling v. Sharpe, 347 U.S. 497, 499-500 (1954). Only equitable relief has been asked, and the Court is concerned only with the question of when an injunction is to issue. See note 3 supra.

6. See note 3 supra. "Gradual" desegregation generally implies one of three methods: 1) A future date is established by which time desegregation must be accomplished. 2) A period of time is permitted before desegregation is to begin. 3) Various forms of piece-meal desegregation, including: desegregation of different geographical areas at different dates; desegregation of different institutional units at different dates, e.g., one school at a time; desegregation of different grades at different dates; progressively incrensing quotas of the number of Negroes to be admitted to a given unit. The proponents of these types of gradual decrees envision a relatively long grace period, because they conceive of these decrees as means for permitting adjustment on the part of the general public. See Clark, Desegregation: An Appraisal of the Evidence, 9 J. Soctal Issues 34-6 (1953); Note, 61 YaLE L.J. 730.

"Forthwith" desegregation, while implying immediacy, has not been so used by the National Association for the Advancement of Colored People, representing plaintiffs in four of the present cases. The N.A.A.C.P. has equated "forthwith" with "as of the beginning of the next school term." See note 27 infra.

There is another form of desegregation which may be considered "gradual" because its implementation would require a decree permitting delay in certain cases. This type would limit delay to the time required to effect the administrative changes necessary to bring about desegregation without a "decrease in the general efficiency of functioning of the institution involved." See Clark, supra at 12 . Where there are no administrative barriers, this approach to desegregation would amount to immediate or forthwith desegregation.

This first section deals only with the legality or propriety of a decree recognizing delay 
cribing wide powers to equity courts have not pertained to this narrow area of equitable discretion. ${ }^{7}$ Moreover, the Supreme Coturt itself has never yet de-

of any sort. For consideration of the type of factors which should determine the degree of gradualness, if a gradual decree is rendered, see below under heading: Factors Determining Gradualness.

7. The Supreme Court has often used sweeping language to describe the range of its discretionary powers in equity cases. See Railroad Comm'n v. Pullman Co., 312 U.S. 496, 500 (1941) ; Hecht Co. v. Bowles, 321 U.S. 321,329 (1944) ; Eccles v. Peoples Bank, 333 U.S. 426, 431 (1948) ; Alabama Comm'n v. Southern Ry., 341. U.S. 341, 361 (1951) (concurring opinion of Frankfurter, J.). It has long been recognized that equity courts can adapt their decrees to unusual circumstances. 1 STORY, EQUITY JURISPRudENCE $\& 28$ (14th ed. 1918) ; 1 Poneroy, EQUity Jurisprudence $\$ \$ 111,170,175$ a (5th ed. 1881). Where the public interest is involved, equity discretion is considered to be particularly broad and flexible; the Court has spoken of its power to "balance the interests" and consider the claims of the community in such equity cases. See Porter v. Warner Co., 328 U.S. 395,398 (1946); Virginian Ry. v. Federation, 300 U.S. 515, 552 (1937) ; Hecht Co. v. Bowles, supra at 329. From some of these judicial statements it might seem that the Court in the instant cases has broad discretion to balance public convenience against plaintiffs' claims. However, generalized statements about equity discretion are ambiguous, for they do not specify to which stage of the judicial process they refer. "Balancing of interests" may occur in at lenst five stages in the decision of a case; and most of the broad statements of equity discretion are found in cases relating to one of the first four of these stages, all of which have been passed in the present cases.

In the first place, the Court may balance conflicting interests in determining whether to decide the questions presented by a case. Where important questions of state policy are involved, the Court may remand to a lower federal court with directions to retain jurisdiction pending construction of a statute in a state court. Railroad Comm'n v. Pullman Co., supra; Chicago v. Fieldcrest Dairies, 316 U.S. 168 (1942); AFL v. Watson, 327 U.S. 582 (1946). Or, where thorny issues of local law are intertwined with constitutional issues, and plaintiff has an adequate remedy in the state courts, the Court may refuse to adjudicate the case. Burford v. Sun Oil Co., 319 U.S. 315 (1943) ; Alabama Comm'n v. Southern Ry., supra. Similarly, the Court has declined to enjoin prosecution af criminal cases on the ground that a court of equity will not ordinarily enjoin criminal prosecution. Douglas $v$. Jeannette, 319 U.S. 157 (1943) ; Watson v. Buck, 313 U.S. 387 (1941). Finally, there are cases which the Court has refused to adjudicate because plaintiff has not exhausted his administrative remedies. Petroleum Co. v. Public Service Comm'n, 304 U.S. 209 (1938). All the cases in this first category are essentially formm non conveniens cases and do not become res judicata on the question of relief.

A second area of equitable discretion presents itself when a court determines whether to issue an interim injunction pending adjudication of plaintiff's rights. See Rice Adams Co. v. Lathrop, 278 U.S. 509 (1929).

Thirdly, the Court may balance community interests against those of plaintiff to determine whether he has a right, i.e., whether he is entitled to any relief at all. And the Supreme Court has done this even in the case of such intangible constitutional rights as freedom of speech and the right to due process. See Wieman v. Updegraff, 344 U.S. 183 (1952) ; Joint Anti-Fascist Refugee Committee v. McGrath, 341 U.S. 123 (1951). The Court balances conflicting interests of this nature in the same manner when the question arises in cases where there is no question of equitable relief involved. Compare Saia v. New York, 334 U.S. 558 (1948), with Kovaks v. Cooper, 336 U.S. 77 (1949).

A fourth stage of equity discretion arises where a right has been found to exist and the Court balances conflicting interests to determine whether to grant legal or equitable relicf. 
cided whether it may delay vindication of already adjudicated constitutional rights. 8

Past Supreme Court interpretations of the nature of the rights involved in segregation cases appear to militate against a gradual decree. The Court has frequently emphasized that these rights are inseparable from the individual claimant by terming them "personal and present." In the instant cases, plaintiffs have only a limited number of years of public education remaining. Therefore it can be forcefully argued that postponement of relief would result in partially or totally destroying the very rights the decree is intended to enforce. ${ }^{10}$

See Harrisonville v. Dickey Clay Co., 259 U.S. 334 (1933) ; Beasley v. Texas \& Pacific Ry., 191 U.S. 492 (1903).

In Brown and Bolling, these four stages have already passed, since a right enforceable only in equity has been found to exist. See note 5 supra. The fifth area of equity discretion, where the only question is when to grant equitable relief, presents considerations quite distinct from those involved in other stages. See notes 15-25 infra and accompanying text.

8. The closest the Court has come to deciding this question was in Youngstown Co. v. Sawyer, 343 U.S. 579 (1952). To avert a steel strike which threatened to paralyze the Korean War effort, the President ordered seizure of the steel industry. The government contended that, even assuming the seizure's unconstitutionality; an overriding public interest prevented the issuance of an injunction against the seizure. The Court might have ordered that an injunction issue after the government had had time to avert the emergency. Immediate relief was granted, however, and only Justice Frankfurter's concurring opinion answered the government's argument: "'Balancing the equities' is lawyers' jargon for choosing between conflicting public interests. When Congress itself has struck the balance, ... a court of equity is not justified in ignoring that pronouncement under the guise of exercising equitable discretion." Id. at 609-10.

9. Sweatt v. Painter, 339 U.S. 629,635 (1950) ; MfcLaurin v. Oklahoma State Regents, 339 U.S. 637, 642 (1950) ; Shelley v. Kraemer, 334 U.S. 1, 22 (1948); Sipuel v. Board of Regents, 332 U.S. 631, 633 (1948) ; Missouri ex rel. Gaines v. Canada, 305 U.S. 337, 351 (1938) ; McCabe v. Atchison T. \& S.F. Ry., 235 U.S. 151, 162 (1914).

What the Court considers the significance of "personal and present" rights is indicated by what it said of the Negro plaintiff in Sipuel v. Board of Regents, supre at 633: "The state must provide [a legal education] for her ... . and provide it as soon as it does for applicants of any other group." In Missouri ex rel. Gaines v. Canada, supra, defendants pointed out that the state was providing out-of-state scholarships to Negro law students only until such time as it was feasible to establish in Missouri an entire separate school for Negroes. In ordering the plaintiff admitted to the law school for white students the Court stated: "We cannot regard the discrimination as excused by what is called its temporary character." Id. at 352. The Court emphasized that "petitioner's right was a personal one. It was as an individual that he was entitled to the equal protection of the laws ...." Id. at 351.

10. In its role of amicus curiae in the instant cases, the government has contended that it is no answer to the claim of a particular plaintiff to say that, at some time in the future, others will receive the equality of treatment which is his, plaintiff's, constitutional right. Supplemental Brief for United States on Reargument, Oct. Term 1953, p. 165, Brown v. Board of Education, 347 U.S. 483 (1954).

Some legal scholars assert that an individual has a right only to the extent that the right is enforced by the courts. See Frank, Courts on Tran 9-12, 24-7 (1950); Llewercyz;, The Braxtble Bush 84 (1951); Holmes, The Path of the Low in Collected Legal Papens 168-73 (1952). The Supreme Court has held that plaintiffs in the instant cases have rights 
But neither lack of precedent nor the doctrine of "personal and present rights" necessarily precludes the issuance of gradual decrees in the present cases. Brozen v. Board of Education and Bolling v. Sharpe are unique in their applicability to future litigation challenging segregation in public education, ${ }^{11}$ and in the variety of problems which may exist in the different localities thereby affected.12 Whereas implementation of previous decisions enunciating the "personal and present" doctrine was relatively simple, ${ }^{13}$ the magnitude of the barriers to immediate enforcement of Brozen and Bolling may make a gradual decree inevitable. ${ }^{14}$ If the Court so concludes, it may find some support in past issuance of gradual decrees in actions to enjoin the commission of a tort, in government antitrust suits, and in prior educational segregation cases decided by other state and federal tribunals under the "separate but equal" doctrine of Plessy $v$. Ferguson.

Tort cases in which gradual decrees have been entered have typically been actions to enjoin the continuance of a nuisance or the infringement of a patent. ${ }^{1 n}$ In water rights cases involving pollution or diversion, for example, the Supreme

to non-segregated education. See note 5 supra. If the Court postpones vindication of these rights for a year, it will in fact be denying the rights of those plaintiffs who are completing their last year of public education; further postponement will result in denial to an ever increasing number of plaintiffs. The absurdity of a decision holding that plaintiffs have rights, followed by a decree which in effect denies those rights, is apparent.

11. The decrees in Brown and Bolling will, of course, directly affect only the five counties against whose school boards suit has been brought. And of these, three counties (Wilmington, Delaware, The District of Columbia, and Topeka, Kansas) have already desegregated. New York Times, Oct. 3, 1954, p. 74, cols. 3-8. However, there are over 2,500,000 Negro students in 15,000 segregated schools in the 17 states which maintained segregation prior to the decision. See Federal Security Agency, Statistics of State School SysTEMS $1949-50$, p. 98 , table 36 . It is already apparent that desegregation will be accomplished in a number of states only after each school board has been sued. See note 38 infra. The decrees in the present cases will inevitably determine the type of relief which will be given in these future suits.

12. See notes 28 and 29 infra, and accompanying text.

13. In public education cases, the "personal and present" rights doctrine has been applied only to education on the professional and graduate school levels. Sweatt v. Painter, 339 U.S. 629 (1950) ; McLaurin v. Oklahoma State Regents, 339 U.S. 637 (1950) ; Sipuel v. Board of Regents, 332 U.S. 631 (1948); Missouri ex rel. Gaines v. Canada, 305 U.S. 337 (1938). Each case concerned only a single plaintiff. In none were there any problems such as transferring students or changing curriculum, nor did the decisions affect any large number of students or institutions. See Clark, Desegregation: An Appraisal of the Evidentec, 9 J. Socins Issues 32 (1953). In McCabe v. Atchison, T. \& S.F. Ry., 235 U.S. 151 (1914), which involved personal rights to equality of treatment in public transportation, relief was denied. Shelley v. Kraemer, 334 U.S. 1 (1948) prohibited judicial enforcement of restrictive covenants based on race. Therefore no problems of implementation were involved.

14. See notes 28 and 29 infra.

15. E.g., Wisconsin v. Illinois, 278 U.S. 367 (1929), modified, 281 U.S. 179 (1930), 289 U.S. 395 (1933), 309 U.S. 569, 311 U.S. 107 (1940) (diversion of lake water) ; Georgia v. Tennessee Copper Co., 206 U.S. 230 (1907), modified, 237 U.S. 474 (1915), 240 U.S. 650 (1916) (smoke nuisance); Arizona Copper Co. v. Gillespie, 230 U.S. 46 (1913) (pollution of stream); Westinghouse Air-Brake Co. v. Great Northern Ry., 86 Fed. 132 (C.C.S.D. N.Y. 1898) (patent infringement). 
Court has granted gradual decrees where it appeared that immediate enforcement of claimant's right might bring great injury to the public or inordinate loss to the defendant without bringing proportional benefit to the plaintiff. ${ }^{10}$ To the extent that immediate desegregation in some areas would result in a significant lowering of the quality of education afforded students of all races, these cases may afford a useful analogy. However, since they have involved property rather than personal rights, the analogy is limited. Postponement of equitable relief need not represent delayed vindication of a property right, since monetary damages generally will compensate for any loss thereby sustained.17 But no money value can be assigned to the intangible right to enjoy equal educational facilities. Moreover, whereas plaintiff in the typical nuisance case has the right to enjoy his land "forever,"18 there can be only a limited period of enjoyment of the rights involved in the instant cases.

Gradual decrees have frequently been a matter of necessity in government antitrust suits because of the magnitude of interests involved. ${ }^{10}$ Decrees ordering divestiture of large holdings or reorganization of vast and complex corporations cannot be effected overnight. ${ }^{20}$ Similarly, the administrative difficulties in

16. In Wisconsin v. Illinois, 278 U.S. 367 (1929), gradual relief was granted to several states suing to enjoin withdrawal of water from Lake Michigan by the Sanitary District of Chicago. As the entire sewage system of Chicago was dependent on the withdrawal, granting immediate relief would have involved the risk of a grave health hazard to several millions of people. See also Arizona Copper Co. v. Gillespie, 230 U.S. 46 (1913). There defendants were given time to alleviate water pollution caused by their mining, since ordering immediate relief would have destroyed their industry.

17. In some cases where the courts have postponed the issuance of an injunction on a balancing of the equities, the right has nevertheless been vindicated immediately by granting money damages. See, e.g., Horne v. Mt. Vernon Die Casting Corp., 181 Mrise. 758, 44 N.Y.S.2d 520 (Sup. Ct. 1943), modified, 278 App. Div. 671, 4 S N.Y.S.2d 37 (1st Dep't 1944). There the court granted plaintiff monthly payments equivalent to the depreciation in rental value of his property due to disturbances caused by defendant's munition factory. These payments were to continue until the court found that the enterprise could be enjoined. See also Bailey v. City of New York, 38 Misc. 641, 78 N.Y. Supp. 210 (Sup. Ct. 1902).

18. Because of the potentially infinite duration of the ownership of tangible property, a fee simple estate is defined today in the same manner as it was described by Littleton in the 15th century: "lands or tenements to hold to [the owner] and his heirs forever." 1FoyNIHAN, LAW OF REAL PROPERTY 17 (1940).

19. In Standard Oil Co. v. United States, 221 U.S. 1 (1911), the district court had allowed thirty days for compliance with a decree ordering partial dissolution of defendant's business organization. The Supreme Court held that this period was too short "in view of the magnitude of the interests involved and their complexity." Id. at S1. Gradual decrees were also involved in Schine Chain Theaters v. United States, 334 U.S. 110 (1948); United States v. Crescent Amusement Co., 323 U.S. 173 (1944); United States v. American Tobacco Co., 221 U.S. 106 (1911).

20. See note 19 supra. The decree in Standard Oil Co. v. United States, 221 U.S. 1 (1911), entailed the dissolution of a combination of more than forty corporations and the transfer of stock in the amount of $\$ 90,000,000$. The transactions involved had talken place over a 40-year period. The decree in United States v. American Tobacco Co., 221 U.S. 106 (1911), required transfer of stock and dissolution of a combination involving sixty-five American and two English corporations. 
revamping an entire school system may be so great as to prevent its immediate accomplishment. ${ }^{21}$ However, any analogy here is severely limited, for government antitrust cases are not concerned with vindicating individual rights. ${ }^{22}$

In the cases most similar to those now before the Court-state and lower federal court decisions concerning equality of education under Plessy $v$. Forguson-gradual decrees were sometimes rendered to allow time for accomplishing administrative tasks. ${ }^{23}$ Where Negro school facilities could not be made equal or were non-existent, immediate relief was afforded by ordering plaintiff admitted to the local school for white students. ${ }^{24}$ In other cases, however, decrees were issued allowing defendants a reasonable time to equalize facilities. Plaintiffs meanwhile continued to attend the inferior school. ${ }^{25}$ Although the issue of gradualness was never raised in these cases, ${ }^{20}$ they afford examples of decrees in personal rights cases which take into account the time necessary for solving administrative problems.

21. See notes 28 and $29 \mathrm{infra}$, and accompanying text.

22. In antitrust suits prosecuted by the government, no individual rights are asserted. The government is concerned primarily with securing the public interest, although individual interests are naturally affected by the disposition of the case. The subsidiary position of private rights in government antitrust suits is emphasized by the fact that, if the court issues a gradual decree, no individuals are awarded damages for any injury they sustain because relief was not immediate. On the other hand, private individuals who bring antitrust actions are entitled to damages up to the time when the illegal activities are permanently enjoined.

23. See, e.g., Briggs v. Elliott, 98 F. Supp. 529, modified and aff'd, 103 F. Supp. 920 (E.D.S.C. 1952). There, the district court ordered defendants to remedy inequalities within six months. $98 \mathrm{~F}$. Supp. at 537-8. This entailed revision of curriculum, consolidation of school districts, new transportation facilities, installation of new equipment, and school house construction. $103 \mathrm{~F}$. Supp. at $921-2$. For instances of similar decrees, see note 25 infra.

24. See, e.g., Sweatt v. Painter, 339 U.S. 629 (1950) (could not equalize); Sipuel v. Board of Regents, 332 U.S. 631 (1948) (no facilities for Negroes) ; Missouri $c x$ rcl. Gaines v. Canada, 305 U.S. 337 (1938) (same); University of Maryland v. Murray, 169 Md. 478, 182 Atl. 590 (1936) (same).

In two instances, state courts ordered plaintiff admitted immediately to the local white school even though, theoretically, the facilities could have been equalized. Graham v. Board of Education, 153 Kan. 840, 114 P.2d 313 (1941) ; Belton v. Gebhart, 32 Del. Ch. 343, 87 A.2d 862 (Ch. 1952), aff'd, Gebhart v. Belton, - Del. -, 91 A.2d 137 (1952).

25. See, e.g., Wrighten v. Board of Trustees, 72 F. Supp. 948 (E.D.S.C. 1947) ; and two unreported cases decided in the federal district court in Virginia on April 7, 1948, Smith v. School Board of King George County, and Ashley v. School Board of Gloucester County, Va. For description of these two cases see Frank, Cases on Constitutional Law, 1040-3 (1952).

In two of the cases now before the Supreme Court, the district courts entered gradunl decrees allowing time for equalization. Briggs v. Elliott, $98 \mathrm{~F}$. Supp. 529 , modificd and aff"d, 103 F. Supp. 920 (E.D.S.C. 1952) ; Davis v. County School Board, 103 F. Supp. 337 (E.D. Va. 1952).

26. In several instances, plaintiffs initially claimed the right of immediate relief by admission to the existing schools for whites. See, e.g., Wrighten v. Board of Trustees, $72 \mathrm{~F}$. Supp. 948 (E.D.S.C. 1947) ; Briggs v. Elliott, 98 F. Supp. 529 (E.D.S.C. 1952). However, once the lower court upheld the validity of the segregation laws and ruled against admittance to the schools for whites, plaintiffs did not contest the gradual decree which allowed time for performing administrative tasks. See note 23 supra. 


\section{Factors Determining Gradualness}

Plaintiffs in the instant cases concede that conditions in certain areas may make immediate desegregation impossible. ${ }^{2 \pi}$ Problems of curriculum, transportation, and reallocation of students and teachers must be solved merely to get the two racial groups into the same schools. ${ }^{28}$ Another serious consideration is that, despite the requirements of Plessy, Negro children in many communities have been provided with an education significantly inferior to that afforded

27. Brief for Appellants on Reargument, Oct. Term, 1953, p. 193, Brown v. Board of Education, 347 U.S. 483 (1954).

The National Association for the Advancement of Colored People, representing plaintiffs in all but the District of Columbia case, contended that the Court had no equitable discretion to render a gradual decree, but did not insist that desegregation take place in the middle of a school term. Id. at 190-3. Alternatively, the N.A.A.C.P. maintained that, even if the Court should decide that equity discretion might permit gradual enforcement of personal, constitutional tights, there were no relevant factors that could justify postponing relief beyond the beginning of the next school term. Ibid.

The 1952 brief for the United States as amicas curiae had contained the first proposals for gradual relief. While expressing the belief that a program for orderly transition would lessen popular antagonisms, the factors which the government indicated should be considered as grounds for postponing relief were essentially administrative. The government brief filed in answer to the question put forward by the Court in its order of June Sth, 1953, generally followed the proposals of the 1952 brief. However, it suggested a time limit of one year for accomplishing desegregation. Supplemental Brief for the United States on Reargument, Oct. Term, 1953, pp. 186-7, Brown v. Board of Education, 347 U.S. 483 (1954).

The defendants' position was somewhat unclear. On oral argument Justin Mcoore, appearing in behalf of the Virginia school authorities, stated: "... If there should be this unhappy, unfortunate decree ... the case should be remanded ... about all we can say is we feel the courts should be given the broadest discretion to act along reasonable lines." Transcript of Argument, Davis v. County School Board, December 14, 1953, p. 52, decided sub nom. Brown v. Board of Education, 347 U.S. 483 (1954). The brief of Appellees in Briggs v. Elliott, indicated a belief that antitrust cases constituted sufficient authority for gradual decrees in these cases. Brief for Appellees, Briggs v. Elliott, Oct. Term, 1953, pp. 81-2, decided sub nom. Brown v. Board of Education, 347 U.S. 483 (1954).

None of the parties indicated which factors, in its opinion, might be considered in determining the degree of gradualness, and which should be disregarded.

28. See Supplemental Brief for the United States on Reargument, Oct. Term, 1953, pp. 170-2, Brown v. Board of Education, 347 U.S. 483 (1954). The government also there points out that tax laws will have to be changed in some states, administrative duplications eliminated, and school districts consolidated and rezoned.

Extensive changes in curriculum may be required because some communities have made different courses available to the two races. A common method of proving inequality has been to show differences in curriculum. See Graham v. Board of Education, $153 \mathrm{Kan}$. 840, 845, 114 P.2d 313, 317 (1941) ; Briggs v. Elliott, 103 F. Supp. 920,922 (E.D.S.C. 1952). In the unreported case of Smith v. School Board of King George County (D. Va., April 7, 1948), the superintendent of schools stated that the two types of instruction were offered with a view to equipping the children for different positions in life. Frask, CASES os: Co:STITUTTONAL LAW 1042 (1952).

Where school districts are consolidated and children from a wider area attend the same school, transportation may have to be provided although it was previously unnecessary. In other instances, transportation has been available only to one race. See Belton v. Gebhart, 32 Del. Ch. 343, 361, S7 A.2d 862, 871 (Ch. 1952). 
whites. ${ }^{20}$ Putting Negro and white children of the same grade but different levels of preparation into one classroom could prove detrimental to the education of both. ${ }^{30}$ The Court's decision appears to be predicated on the assumption that desegregation will provide the plaintiffs with an education superior to that previously afforded. ${ }^{31}$ If this be so, the Court's aim in formulating the decrees should be to improve the quality of education available to plaintiffs. The decrees in these cases should therefore be sufficiently flexible to resolve administrative problems where these are such that immediate desegregation would temporarily reduce the quality of Negro education even below its previous level.

Economic factors present no obstacle to immediate desegregation. Not only is amalgamation less expensive than maintaining the present segregated school system, ${ }^{32}$ but two billion dollars would be required for equalization of all Negro schools on a "separate but equal" basis. ${ }^{33}$

29. See Carter, The Court's Decision and the South, Reader's Digest, Sept. 1954, pp. 51-6. Where the Negro schools are inferior the disparity in academic achicvement of white and Negro students increases with each grade. Ibid. Inferior achievements of Negro students in certain areas of the South are due to a number of factors but can be traced primarily to economic discrimination in allocating school funds. Average per capita expenditures throughout the South for public education in 1951-52 were $\$ 116$ per Negro student as compared with $\$ 180$ ger white student. Public Affairs Pamphlet 209, Segregntion and tile Scrools 17 (issued in collaboration with the N.A.A.C.P.). In certain states the disparity is considerably greater. Mississippi's annual expenditures in public education in 1951-52 averaged $\$ 32.55$ per Negro student as compared with $\$ 122.93$ per white student. FEberat. Security Agency Statistics of State School Systems 105 (1950). Also contributing to the poorer education of Negro pupils is the fact that many of their teachers have not had the educational advantages of their white colleagues. Carter, supra. Negro university students are reported to have had difficulty competing with white students because of these handicaps. Public Affairs Pamphlet 209, supra at 12. See also Astrmore, Tuie Negio AND THE SCHOots 43 (1954). See also note 28 sitpra.

30. See note 29 supra. Lowering of standards in mixed schoolrooms is feared by some southerners who otherwise approve the Court's decision. See Carter, The Court's Decision and the South, Reader's Digest, Sept. 1954, pp. 51-6. The prior educational advantages of the white students would be wasted and Negro inferiority feelings might be enhanced if the two groups were thrown indiscriminately together and the instructor forced to find a common denominator for students widely separated in academic achievement. It may be necessary to devise aptitude tests for all students in such cases, placing those who would be unable to keep up with the desired standards for a given grade into special classes, but without regard to race.

31. The Court quoted and adopted as the basis for its holding the findings of the district court in the Kansas case: "a sense of inferiority affects the motivation of a child to learn. Segregation with the sanction of law, therefore, has a tendency to [retard] the educational and mental development of Negro children ...." Brown v. Board of Education, 347 U.S. 481, 494 (1954).

32. The Attorney General of Virginia conceded this in his brief. See Brief for Appellecs, Davis v. County School Board, Oct. Term, 1952, p. 21, decided sub nom. Brown v. Board of Education, 347 U.S. 483 (1954).

33. See estimates made by the United States Office of Education as reported in Supplcmental Brief for United States on Reargument, Oct. Term, 1953, p. 172, Brown v. Board of Education, 347 U.S. 483 (1954). 
Psychological arguments advanced as to the need for indulging deep-rooted racial feelings should be given no weight in formulating the decrees. ${ }^{34}$ No analogy can be derived from past equity cases to support a decree allowing such considerations to delay vindication of a constitutional right. Furthermore, sound policy precludes such a decree. Certainly the irrational opposition of a segment of society cannot be allowed to hamper enforcement of constitutional rights. One purpose of the Constitution is to protect the interests of often unpopular minorities. ${ }^{35}$ Moreover, experiences in both voluntary and compulsory desegregation have clearly demonstrated that the removal of artificial barriers is a most effective way of combating such prejudices. ${ }^{36}$

34. For such arguments, see Brief for Appellees on Reargument, Briggs v. Elliott, Oct. Term, 1953, pp. 77-9, decided sub nom. Brown v. Board of Education, 347 U.S. 483 (1954).

The contention that gradualness is necessary to prevent a "violent emotional renction" seems to be based on the fact that segregation is deeply ingrained in the "habits, customs and usages of the people over a long period of time." Id. at 76-7. To break suddenly with this tradition, the argument runs, would exacerbate racial antagonisms; not only would race prejudice be increased but the entire school system might break down. Id. at 76-9, 846. But the fact is that integration generally decreases racial feelings. See note $36 \mathrm{infra}$. And it is doubtful that any school system will break down because of emotional reactions unless they take the form of overt opposition to enforcement of the Supreme Court's decision. As to such opposition, see text at notes 37-9 infra.

35. See, e.g., Buchanan v. Warley, 245 U.S. 60 (1917) (municipal zoning on basis of race invalid) ; Tucker v. Texas, 326 U.S. 517 (1946) (ordinance prohibiting literature distribution by Jehovah's Witnesses invalid) ; De Jonge v. Oregon, 229 U.S. 352 (1937) (Communists' right of assembly upheld).

36. Racial integration in all aspects of daily living has been successfully achieved on a large scale in the armed forces. While this desegregation was gradual as to each service as a whole, it was immediate as to the individual units involved. The experiences are therefore the same as would be encountered in cases of instantaneous desegregation. No incidents of friction have been reported. Report by the President's Cosisuttes o: EQuality of Opportunity IN THE Arared SeRvices 44 (1950). During the last war a survey was made of the attitudes of white soldiers who served with Negroes in combat units. Three out of four stated that their attitudes toward Negroes had improved as a result. Id. at 53. Similar findings have been made in studies of desegregation in religious groups, hospitals, health services, public accommodations, recreational facilities, organized sports, employment, and educational institutions. These findings were made in areas throughout the country. Mrethods of desegregation included desegregation compelled by community officials, the legislature or judiciary, as well as voluntary desegregation. See Clark, Desegregation: An Appraisal of the Evidence, 9 J. Soctal Issues (1953); Appendix to Appellants' Briefs: A Social Science Statement, Oct. Term, 1952, Brown v. Board of Education, 347 U.S. 483 (1954); Note, 61 Y ALE L.J. 730 (1952).

A group of social scientists which studied past instances of desegregation in connection with the cases now before the Court, concluded that gradual, "segmentalized" desegregation is less effective than immediate desegregation, and increases the chances of resistance and resentment. Clark, supra at 42-8. Gradual desegregation may be interpreted by both white and Negro as evidence of vacillation and indecision on the part of authorities, and a reflection of their own belief that there is something inherently dangerous in the desegregation process. Adorno, et al., The Authoritarian Persomality (1951). And whites involved in the first stages of desegregation tend to resent being "guinea pigs." Tupros, Cosssusirs: 
The Court's equity discretion does not extend to permitting delay based on the possibility that social or political upheavals may result from enforcing the decisions. ${ }^{37}$ Any indication that the courts will stay their hands to avoid the consequences of opposition to their decrees would be an open invitation to coercion of the judiciary. ${ }^{38}$ The principle that illegal acts should not be allowed to deprive a person of his constitutional rights should certainly apply to threatened action in defiance of the Court's authority. ${ }^{30}$

IN CRIsIs 71 (1953) ; Culver, Racial Desegregation in Education in Indiana, 23 J. Nearo Educ. 296-302 (1954); Clark, supra at 46.

Professor Clark contends that it is erroneous to believe that education, propaganda, and non-authoritarian approaches are necessary before social changes such as desegrcgation can be effected. When concrete, external pressures conflict with subjective, irrational motivations, the individual tends to modify his attitude to conform with the authoritatively established pattern of behavior. This is particularly true in the case of segregation, where individual racial attitudes are supported by observing the practice of segregation. When this support is removed and the opposite attitude is supported by law, prejudices will tend to be changed. Id. at 42-8.

37. See Buchanan v. Warley, 245 U.S. 60, 81 (1917), where, in holding discriminatory municipal zoning invalid, the Supreme Court stated: "It is urged that this proposed segregation will promote public peace by preventing race conflict. Desirable as this is, and important as is the preservation of the public peace, this aim cannot be accomplished by laws or ordinances which deny rights created or protected by the Federal Constitution."

38. In its amicus curiae brief filed in the forthcoming arguments, Florida warns that violence will result from immediate enforcement. N.Y. Times, Oct. 2, 1954, p. 1, col. 1. Other forms of opposition include threats of legislative action to abolish the public schools should no other means of maintaining segregation be found. Mississippi has already passed a constitutional amendment authorizing the school boards to take such action if necessary, and the Alabama legislature has recommended a similar amendment. Time, Sept. 27, 1954, p. 60 .

In two instances where school boards have desegregated in advance of the Court's decree, protest meetings accompanied by threats of violence have caused a return to segregation. Time, Sept. 27, 1954, p. 60; N.Y. Times, Oct. 2, 1954, p. 18, col. 1. However, when the school board of Fairmont, West Virginia, obtained an injunction prohibiting demonstrations and threats against its integration policy, and the county judge (Meridith) promised to enforce the injunction if he had to "fill the jail until their feet are sticking out the windows," opposition ceased immediately. N.Y. Times, Oct. 1, 1954, p. 32, col. 2. Duc to the firm action of local officials, demonstrations in Baltimore and Washington, D.C., waned after a week. N.Y. Times, Oct. 7, 1954, p. 25, col. 8. Past experiences with racial conflicts demonstrate that the prospect of firm and unwavering enforcement can prevent incidents. See Note, 61 YaLE L.J. 730, 743 (1952). See also letter from Dr. Kenneth Clark to N.Y. Times, Oct. 8, 1954, p. 22, col. 7, concerning Gov. Boggs' responsibility for disturbances in southern Delaware.

Subsequent to publication of Dr. Clark's letter, the Attorney General of Delaware appeared as amicus curiae in the Chancery Court requesting an injunction ordering reinstatement in the Milford High School of ten Negro students. They had been expelled because of public opposition to integration. The injunction was granted. N.Y. Times, Oct. 15, 1954, p. 1 , cols. 6,7 .

39. When people are led to act illegally because an individual exercises his legal right, the proper procedure is to protect the legal right, if necessary by punishing those who use illegal means to oppose it. See Sellers v. Johnson, 163 F.2d 877, 883 (8th Cir. 1947), where the court held that the police were not entitled to prevent the Jehovah's Witnesses from 


\section{Procedures for Formulating the Decrees}

The Supreme Court's questions regarding the procedure to be followed in fixing the details of the decrees concern mainly issues of policy, not of law. The Court's dispositive powers are broad enough to provide for a decree of any specificity. 40 The long standing practice of the Supreme Court has been to remand the case rather than to enter a decree itself. ${ }^{41}$ It has, however, frequently formulated decrees in considerable detail, and designated procedures to be followed by the lower courts on remand.2 The Court's decree should be specific enough to insure uniform and effective implementation of the present decisions and to guide future litigants. On the other hand, the Court's often expressed sentiment that details of decrees are best left in the hands of lower court judges is particularly applicable here because of the varied conditions in the different localities affected by the segregation decisions. ${ }^{43}$ The decrees in these cases

holding their meeting in order to avoid public conflict. Rather, the police should have acted against the mob which threatened violence.

See also Schneider v. State, 308 U.S. 147 (1939) ; Terminiello v. Chicago, 337 U.S. 1 (1949) Hague v. CIO, 307 U.S. 496 (1939); Cantwell v. Connecticut, 310 U.S. 296 (1940) ; Stromberg v. California, 283 U.S. 359 (1931). But cf. Feiner v. New York, 340 U.S. 315 (1951).

40. The dispositive powers of the Court are set out in 62 STAT. 922 (1948), 28 U.S.C. $\$ 2106$ (1952). The only limitation placed on the Court is that its judgments should be "just under the circumstances."

41. There are instances in its history when the Supreme Court, functioning under older statutes, both formulated and entered decrees in cases arising from state or federal courts. See, e.g., The London Packet, 5 Wheat. 132 (U.S. 1820); Tyler v. Magwire, 17 Wall. 253 (U.S. 1872) ; Gibbons v. Ogden, 9 Wheat. 1 (U.S. 1824).

42. See, e.g., decrees in United States v. Paramount Pictures, 334 U.S. 131 (1948); Schine Chain Theaters v. United States, 334 U.S. 110 (1948).

43. Much discretion is vested in federal district courts to mold their decrees to the exigencies of the individual case. The Supreme Court has frequently stated that details of decrees are best left to district court judges who are closer to the facts of the case and who may spend considerable time hearing evidence on the decree alone. See International Salt Co. v. United States, 332 U.S. 392, 400-01. (1947) ; United States v. National Lead Co., 332 U.S. 319, 329-36 (1947) ; United States v. Crescent Amusement Co., 323 U.S. 173, 185 (1944).

The government suggested remand to the district courts in the present cases, with instructions to enjoin the defendants forthwith from using race or color as a basis of admission to their public schools "provided, however, that if the defendants show that it is impracticable or inequitable to grant the plaintiffs the remedy of immediate (i.e., at the beginning of the next school term) admission to nonsegregated schools, the court shall order the defendants to propose and, on approval by the court after a public hearing, to put into effective operation a program for transition to a nonsegregated school system as expeditiously as circumstances permit." Supplemental Brief for the United States on Reargument, Oct. Term, 1953, p. 186, Brown v. Board of Education, 347 U.S. 483 (1954). The defendants also recommended remand to the district courts which, however, in their view could not impose a particular plan of desegregation upon the local school boards, as this would impinge on the prerogatives of a sovereign state. Brief for Appellees on Reargument, Briggs v. Elliott, Oct. Term, 1953, pp. 845, decided sub nom. Brown v. Board of Education, 347 U.S. 483 (1954). Defendants' position apparently was that the lower courts could fix 
should clearly indicate the types of administrative factors which may justify delay. ${ }^{44}$ Each district court, on remand, may then hold hearings as in the antitrust cases to determine to what extent, if any, such factors exist, and the time required to overcome them. ${ }^{45}$

The Court's question 5 (c) concerns the appointment of a special master to hear new evidence to assist it in formulating a decree. ${ }^{46}$ Appointment of a master in a case where the Court functions as an appellate tribunal would be unprecedented. ${ }^{47}$ And it is dubious whether a special master acting for an appellate tribunal could hear new evidence, since there is question as to such a court's own power to do so. ${ }^{48}$ Furthermore, if it is decided that the lower courts shall hold hearings to adapt the rate of desegregation to the requirements of each situation, a master would be of little value.

Since, by their nature, the rights involved in these cases require prompt vindication, no considerations of mere convenience should delay implementation of the Court's decision. A decree directing the lower court to determine the minimum time required for solving unavoidable administrative impediments to immediate desegregation would enforce plaintiff's rights as effectively and realistically as possible.

a time limit in each case but that it would be for the local school authorities to determinc the manner of desegregation.

The N.A.A.C.P., because of its view that a gradual decree would not properly protect plaintiffs' rights, did not suggest terms for such a decree. Brief for Appellants on Reargument, Oct. Term, 1953, p. 195, Brown v. Board of Education, 347 U.S. 483 (1954).

44. The Court's oft-expressed reluctance to involve the judiciary in administration of complex and detailed matters, or in interference with the internal affairs of the states, goes only to the Court's discretion and not to its power to act. See United States v. Paramount Pictures, 344 U.S. 131, 165 (1948). And see Nebraska v. Wyoming, 325 U.S. 580, 616 (1945), where the Court stated: "The difficulties of drafting and enforcing a decree are no justification for us to refuse to perform the important function entrusted to us by the Constitution."

45. Since large cities such as Washington, D.C., Wilmington, Delaware, and Baltimore, Md, have successfully desegregated in the course of a summer, it is improbable that administrative considerations would justify delay beyond the "next school term" in most cases. Communities in Missouri and Arkansas have also desegregated without diffictlty. See Time, Sept. 27, 1954, p. 60.

46. See note 3 supra.

47. In cases where the Supreme Court functions as a court of original jurisdiction, appointment of a master to find the facts has been common. See, $\varepsilon . g$., Illinois v. Indiana, 321 U.S. 752 (1944); Vermont v. New Hampshire, 282 U.S. 796 (1930); Wisconsin v. Illinois, 278 U.S. 367 (1929).

48. The Supreme Court has held several times that an equity court cannot hear new evidence in the exercise of its appellate jurisdiction. See, e.g., Blease v. Garlington, 92 U.S. 1 (1875). In so far as these cases rested on the statutory prohibition of 1803 (2 STAT. 244) they are not controlling since that provision was repealed by the Judiciary Act of 1948,62 STAT. 923 (1948), 28 U.S.C. \&2106 (1952). However, the Court has stated that, apart from statute, the established chancery practice precludes hearing of new evidence on appeal. Russell v. Southherd, 12 How. 139, 159 (U.S. 1851). Established practice may remain although the statute has been repealed. 